\title{
Tutoring Functions in a Blended Learning System: Case of Specialized French Teaching
}

\author{
Nadia Chafiq \\ Member of the multidisciplinary Laboratory in Sciences and \\ Information, Communication, and Education Technology \\ (LAPSTICE) \\ Observatory of Research in Didactics and University \\ Pedagogy (ORDIPU) \\ Faculty of Sciences Ben M'Sik, University Hassan II of \\ Casablanca, Morocco
}

\begin{abstract}
There is an emergence of blended learning today which combines diversified teaching methods, alternating distance learning and classroom learning. As a matter of fact, most Moroccan universities are presently aware of the importance of this approach, which appears to be most suited for Moroccan university context. This article is meant to identify the different roles of the tutor within the blended learning system. This is more precisely to present an experience of implementing a hybrid learning system by using the "FOUL" platform. The introduction of this platform is accompanied by a need for developing new skills, be it for a teacher or a student. This experience is motivated, on the one hand, by the supply of additional online resources as a complement to a face-to-face classroom method, on the other hand by the personalization of learning and riding out classroom-based learning constraints (e.g. in terms of time, place, staff ...) as it is the case in universities. This article intends to address the above problems by analyzing student responses to questionnaires and processing the content of synchronous communication between learners/learners and learners/online tutors in order to identify and analyze tutoring functions. It can be concluded that the success of a hybrid learning system is conditioned by the presence of some basic functions such as: pedagogical, organizational and socio-motivational functions. These functions remain dominant in a hybrid learning system.
\end{abstract}

Keywords-Learning scenario; Tutoring functions; platform; linguistic proficiency; Interaction

\section{INTRODUCTION}

The sociolinguistic question is one of the issues in Morocco. At the level of secondary education, the scientific disciplines are being taught in Arabic. The Arabization is not carried out at the level of university and the students are dealing with scientific courses in French and so facing serious linguistic difficulties. Since its implementation in universities with an open access (2003), the teaching of language and communication has been the object of many pedagogical reforms tempting to make it more coherent and better adapted to the real needs of students. The last reform (2014) renames the module "language and Communication (LC)" which is, currently, entitled "Language and Terminology". The latter is carried out in the first and second semester with a timetable of 45 hours each shared between the teachers in classroom and

\author{
Mohammed Talbi \\ Laboratory of Analytical Chemistry and Physical Chemistry \\ of Materials \\ Observatory of Research in Didactics and University \\ Pedagogy (ORDIPU) \\ Faculty of Sciences Ben M'Sik, University Hassan II of \\ Casablanca, Morocco
}

online via the Moodle platform. Therefore, a new system referred to as" "Hybrid System" is being established.

The teaching of the French language in Moroccan universities adopt the spirit of the Common European Frame of Reference for languages (CEFRL) whereof its existence is motivated by the necessity: of a common basis for the making of language programs, the design of exams and textbooks ; of a descriptive frame to delineate the learning objectives of a language so as to use it in order to communicate ; to set down the knowledge and the skills to acquire in order to possess an efficient linguistic behavior (CEFRL, 2001, p.9).

To start with, the teaching of the module Language and Terminology (L/T) in The Moroccan University has been particularly designed for a large and not highly motivated arabized turnout, in a hurry and with few resources. The computing tool has been cogently imposed as a supplement meant to improve this situation. To begin with, once the context and issues of this research are laid out, the Faculty of Sciences Ben M'Sik student's responses to questionnaires will be analyzed. Then the main constraints related to the hybrid system and the tutoring functions of the teacher will be defined. Finally, the results will be analyzed and discussed in order to identify the key factors to make the hybrid system operational within the Moroccan university.

\section{CONTEXT}

The Moroccan university receive a "massive number of students", but beyond the quantitative aspect of the phenomenon, it is important to take into account that at the same time as this "mass" grows, it also diversifies and this is precisely what makes it necessary, and even indispensable, to implement training systems that can meet the wide-ranging needs of current learners. Therefore, training systems must "no longer be what they had been" and then should adapt to the needs of students. The approaches that offer the most autonomy to the student, and which are highly praised: hybrid approach, workshops and language laboratory.

In Morocco, as in other countries, teachers seem reluctant to exploit such systems despite the fact that much effort has been made to further promote the development of e-Learning and to make the hybrid system operational within the Moroccan university so that it would be on the same footing as 
the international universities. The choice of this system will grant Moroccan students a latent period by continuing to offer hybrid trainings, alternating face-to-face and distance classes, before switching to the 'all on line'.

By working in a network or alone on the computer, some students who are not used to learning autonomously would be tempted to abandon the program at the slightest difficulty. It is therefore appropriate within the framework of the hybrid system to involve trainers capable of designing well-structured programs enabling learners to exploit their time efficiently. Online tutors must also be competent to better support students' commitment.

\section{ISSUE}

Among the most important constraints facing the implementation of the hybrid system at present are those of an organizational and pedagogical nature. This paper argues that if the hybrid system is associated with supreme supervision and mentoring, it will be able to overcome these constraints and help students develop their language and communicative competence.

However, the tutor, as competent as they may be, cannot be effective, without setting up normative systems regulating the e-learning project, and including formal elements such as laws, structures (e.g. a language centre), The number of tutors should, for example, be proportional to the number of learners, the calculation of the teaching hours which behoove the tutor at the e-Learning level, the reward systems, etc. A prerequisite is therefore to institute an ethical organizational climate for the elearning project that influences the tutors' decision-making. Tutoring is often the last thing designers of learning systems are interested in, only concerned with, technological solutions.

Thus, questioning tutoring raises several questions about the identity of tutors, their roles, the planning of their actions, and so on. Moreover, in a context of hybrid training, the tutor's function is diversified and renewed, which necessitates a reflection on a descriptive model of the tutors' functions. For example, it is important to question the interventions at distant but also face-to-face classes and how they can be complementary. In addition to their traditional pedagogical objective linked to the transmission of knowledge, tutors must be able to tackle the technological, organizational, socioaffective, relational and metacognitive problems that punctuate the activities of the learners: What are the fields of intervention of the tutor in the context of a hybrid system? What are the tutorial functions of the language tutor (Analysis of participatory feedbacks-Moodle)? What new supportive skills are needed for these tutors within the hybrid system?

\section{Methodological Choice}

\section{A. Techno-pedagogical environment}

A sample of 120 physics students (Level A2), were the subject of this research. (see table below).
TABLE I. EXPERIMENT / HYBRID SYSTEM

\begin{tabular}{|c|c|c|c|c|c|}
\hline Platform & $\begin{array}{l}\text { Number } \\
\text { of } \\
\text { tutors }\end{array}$ & $\begin{array}{l}\text { Number } \\
\text { of } \\
\text { students }\end{array}$ & Public & $\begin{array}{l}\text { Face-to-face } \\
\text { teaching }\end{array}$ & $\begin{array}{l}\text { Remote } \\
\text { teaching }\end{array}$ \\
\hline $\begin{array}{l}\text { FOUL } \\
(2014 / 2015)\end{array}$ & 4 tutors & 120 & $\begin{array}{l}\text { A2 } \\
\text { level } \\
\text { S1 }\end{array}$ & $\begin{array}{l}\text { 25H (Cap } \\
\text { university } \\
\text { handbook/ } \\
\text { environment) }\end{array}$ & $\begin{array}{l}15 \mathrm{H} 3 \\
\text { pedagogical } \\
\text { online } \\
\text { scenarios }\end{array}$ \\
\hline
\end{tabular}

"FOUL" (French for University Objectives) is the suggested platform for experimentation at the Faculty of Sciences Ben M'Sik. This platform was created with Moodle (http://tice-lt.info/foul/). Then the content of the platform was based on the results of an analysis of student's needs. FOUL consists of thirteen units corresponding to thirteen different themes related to the syllabus of the first year of the bachelor degree, and they are: The elements of nature, shapes and colors, Scientific press, the digestive system, the influence of light on plants, the immune system, GMOs, nuclear waste management, IT security, renewable energy, nanotechnology, the forest ecosystem and application form.

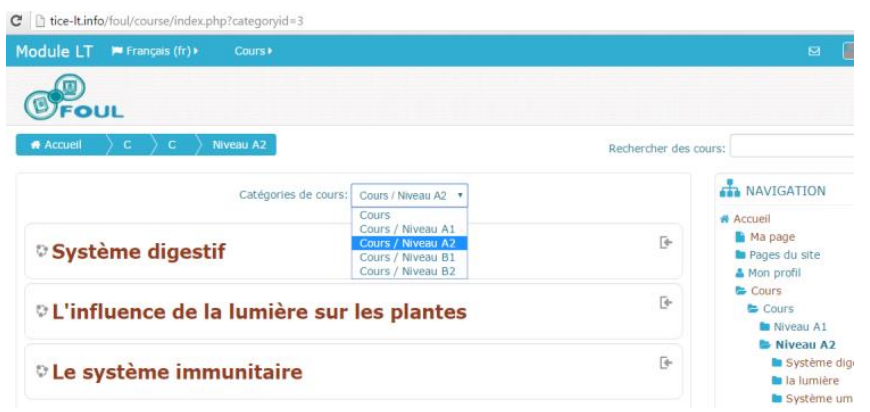

Fig. 1. Example of a figure caption - FOUL Platform

Each of the units is then divided into six sections: identification of the scenario, awareness, exposure, appropriation, assimilation / production and evaluation (of a project). The first three are a set of micro-tasks, in accordance with action-oriented approach - or approach tasks recommended in 2001 by the European Framework of Reference for Languages (CEFR now), help to achieve a macro final-task, which is the "educational project" in the case of FOUL.

Video documents, texts, images and sound are used to trigger the achievement of different activities. Finally, this training involves the presence of a tutor, which must take place in the various Moodle tools used by students, namely e-mail, chat, forum and at the correction of the activities. This tool has been integrated in our educational system to develop the hybrid scenario and promote the acquisition of new knowledge and skills by students outside the classroom. The online courses will be complemented by the French handbooks "Cap university" that address A2 level students, as classified by the Common European Framework for Languages (CEFR) and aims to get them to B1 level. 
First, the investigatory work done was based on online survey on 120 students to collect information on the use of tools of the platform, their perceptions of mentoring and online learning difficulties. Furthermore, to better understand the diversity of situations actually experienced by students during the hybrid system and to avoid the limitations of the "quantitative" survey. Interviews have been conducted and the content of synchronous communications between students / learners and learners / online tutors have been analyzed. This helped in reflecting upon tutorship functions

\section{B. Presentation of the model used in research}

Implementing hybrid systems is a complex process. On one hand, it takes into consideration several aspects:

The organization of the training, roles of involved parties, the lesson plan and resources. On the other hand, it is part of a dynamic process of adapting to changes in society, technology and training paths. Making the choice of a hybrid system that implies changes in terms of organization, teaching and learning, hence the need to think about modeling. According to Gilles Willett [1]"there is a tendency to view the models as being first in the schematic representation to describe and illustrate reductively, simply and functionally the essential features of an object, of a system or a process."

The models are used to create some order between the elements of a complex whole and represent the links, the connections and the relationships between these elements. No model can be applied at all levels of analysis and all research objectives. The model used in this research sets, reports and describes the tutorship functions as part of a hybrid system (see diagram below).

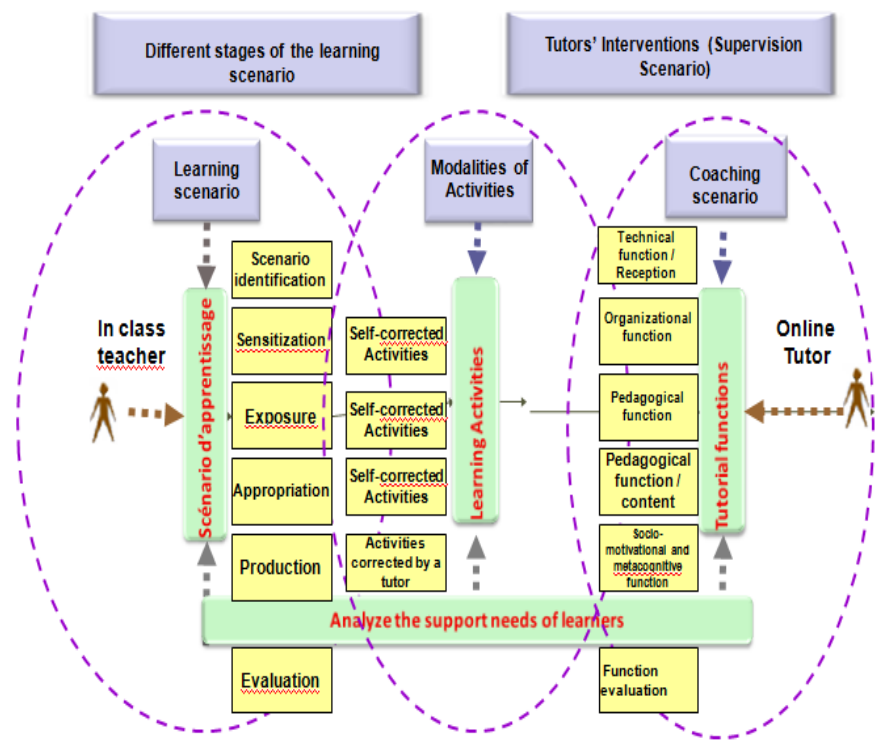

Fig. 2. Descriptive Model of tutorship functions as part of a hybrid system

The model describes the distribution of roles of remote tutors to face-to-face tutors, the functions of supervision and modalities of learning activities. Indeed, the hybrid system requires from the teacher a rigorous training organization and a clear definition of remote tutor intervention methods and faceto-face teaching. It is a complex system that requires anticipation of actions related to both the field of supervision and that of learning. Indeed, the anticipation of educational activities refers to the notion of the pedagogical scenario and it comes in two forms, the learning scenario and the supervision scenario (Quintin, JJ \&Depover, C. \&Degache, C. (2005))[2].

At the platform level (FOUL), a learning scenario will be described as a series of steps which are: identification of the scenario, awareness, exposure, ownership, production and evaluation (of a project). As for the supervision scenario, according to the model above, it defines the tutorship functions of the language tutor in the learning process.

\section{ANALYSIS OF RESULTS}

\section{A. Analysis of the tools of the tutor}

The platform FOUL provides tools to help the tutor in his coaching task: consulting tools to give access to knowledge (links, documents, books) but also tools of exchange (Forum, chat, assignment, wiki, and logbook) to support the construction of knowledge. The table below demonstrates the analysis of two of the tutor tools: Forum and Chat.

TABLE II. TUTOR TOOLS / FORUM AND CHAT

\begin{tabular}{|l|l|l|}
\hline Platform & What is a forum? & What is Chatting? \\
\hline To Pass on information? & $\begin{array}{l}\text { YES- Careful of the } \\
\text { loss of information }\end{array}$ & $\begin{array}{l}\text { YES- in the case of } \\
\text { a } \\
\text { Initial chatting }\end{array}$ \\
\hline $\begin{array}{l}\text { Communicate and } \\
\text { interact? }\end{array}$ & yes & Yes \\
\hline $\begin{array}{l}\text { Follow the activity of } \\
\text { learners? }\end{array}$ & yes & Difficult \\
\hline Co-creation of content ? & yes & Possible with wiki \\
\hline Evaluate the learners? & yes & $\begin{array}{l}\text { Quite difficult } \\
\text { especially in } \\
\text { languages }\end{array}$ \\
\hline
\end{tabular}

In the student survey, students were asked to give their opinion on the use of tools of the FOUL platform (Chat and Forum). For chatting, 50\% of students consider this tool useful for team meetings. Indeed, in general, students use the chat tool to ask questions on the course to online peers or to contact the teacher.

However, there have not been many exchanges. Initially, there was willingness on the part of the tutors, it was originally planned that this platform will be used as a tool for exchange but it was noticed that there were some attempts; only a few words, perhaps in two or three sessions, were observed. The lack of communication via the platform determined by the hybrid nature of the system: the weekly gatherings at face-toface sessions made the interactions artificial via the platform. This caused a "diversion" effect ("catachresis" according to Rabardel, 1995) [3]: very little used as an exchange tool (which is one of its main functions), the platform has instead served as a tool to progressive management for achieving group project.

Note also that tasks exchange goes beyond chat sessions especially in exchange forums with the teacher and the one among learners. Another item that evaluates the interaction through the platform comes from the participation in the Forum. Almost $85 \%$ (very useful and helpful answers) of students believe that the use of the forum as a tool is useful. 
Through the forum, students can ask questions that the teacher or other students can answer and these questions are sometimes mentioned during face-to-face sessions.

This Forum is an opportunity to represent each student and to trigger interactions during training. The forum allows students to submit documents or web links that seem interesting and that could be useful for their peers. Where each of the proposed tasks leads to a discussion in a forum and thus in a public space, it is also about empowering students to allow them be in charge of their training and to get them to discuss issues that were mentioned during the course or exchange notions that would further the development of the face-to-face classes.

A mid-term evaluation of this blended learning experience allowed us to identify some ethical issues at the forum (use of SMS language or the problem of plagiarism) it is mainly during the exchange on a given subject, the student copies extracts from the internet to put them in the forum. What are the reasons for these deviations among distance learners (FOUL platform)? Among other reasons: it is when the teacher is not there. Because of this lack, less "finished" work submitted at the platform will be witnessed.

\section{B. function of the tutor in the hybrid system}

The introduction of FOUL platform requires developing new skills, be it the teacher or the student. The hybrid system uses different teaching methods from those in the "face-toface" training. Kern (2006) [4] points out the importance of training teachers because; "Rethinking the role of teacher means rethinking teacher training."

Two major functions are distinguished for teachers who engage in hybrid training systems: instructional designer and tutor. Regarding the first, Pothier (2003) [5] believes that teachers are the best people for this kind of function as they hold three kinds of expertise needed for this: the content, the likely reactions of learners and the teachers on site aid. The specific nature of online exchanges require their fourth expertise that is attached to the support which it's called technical expertise. Glikman (2002) [6] considers that teachers should have some "technical culture" of the tools used. It is necessary that the teacher knows the implications of the use of the platform: correcting exercises on time (as soon as possible after being submitted in the platform), checking his account on a daily basis if possible (to check e-mail sent by the students), and participation in any forum launched on the platform.

In case of a non active participation of the teacher, students will not see the importance of submitting files if they won't get feedback or correction. Feedback is important for student motivation and good participation on the platform.

In an essay on the introduction of new jobs related to ICT (information and communication technologies), Mangenot (2005, 163) [7] suggests to distinguish four main types of skills: basic technological skills "they will also be a prerequisite for most other functions," those related to the educational support, those related to management and those related to the design of technological resources. So from this experiment, it can be noticed that the skills that a language teacher has to develop are part of the scope of the design of techno-pedagogical tools as well as the online tutoring for teaching French for special purpose.

As part of this experiment, the teacher plays an important role when his functions are of different nature that may be - to use the typology of Rodet (2011) [8] - summarized in the table below:

TABLE III. FIELD OF INTERVENTION OF THE TUTOR / LANGUAGE ADAPTATION (RODET, 2011)

\begin{tabular}{|l|l|l|l|}
\hline Cognitive & Metacognitive & Motivational & Socioaffectifve \\
\hline $\begin{array}{l}\text { Indicate } \\
\text { objectives }\end{array}$ & $\begin{array}{l}\text { Explain the } \\
\text { importance of } \\
\text { each activity }\end{array}$ & $\begin{array}{l}\text { Encourage } \\
\text { participation }\end{array}$ & Build interest \\
\hline $\begin{array}{l}\text { Work on the } \\
\text { disciplinary } \\
\text { content }\end{array}$ & $\begin{array}{l}\text { Facilitate } \\
\text { planning }\end{array}$ & $\begin{array}{l}\text { Reinforce } \\
\text { motivation }\end{array}$ & Show presence \\
\hline $\begin{array}{l}\text { Find a suitable } \\
\text { methodology }\end{array}$ & $\begin{array}{l}\text { Evaluate } \\
\text { strategies }\end{array}$ & $\begin{array}{l}\text { Encourage and } \\
\text { congratulate }\end{array}$ & $\begin{array}{l}\text { Customize } \\
\text { participation }\end{array}$ \\
\hline $\begin{array}{l}\text { Correct and } \\
\text { advise }\end{array}$ & $\begin{array}{l}\text { Assist in self } \\
\text { evaluation }\end{array}$ & $\begin{array}{l}\text { Facilitate group } \\
\text { collaboration }\end{array}$ \\
\hline
\end{tabular}

As for the overall impression on the quality of pedagogical supervision during the test, some students have expressed disinterest in hybrid system and were dissatisfied with the lack of coaching and pedagogical support for students:

"I expected to have my uploaded activities corrected, there are activities which were posted but have not been corrected, so we do not know the result ". (Student SMP).

As mentioned above, it noticed that there is insufficient tutorial help in the platform activities. To analyze these constraints related to tutoring, it was first about tracing interactions between tutors / students to analyze tutorship functions of the four tutors (see table below).

TABLE IV. DESCRIPTION OF THE FREQUENCY OF TUTORSHIP FUNCTIONS FROM THE PLATFORM

\begin{tabular}{|l|l|l|l|l|}
\hline $\begin{array}{l}\text { Tutorship } \\
\text { functions }\end{array}$ & Tutor 1 & Tutor 2 & Tutor 3 & Tutor 4 \\
\hline $\begin{array}{l}\text { Pedagogical } \\
\text { function }\end{array}$ & + & + & + & + \\
\hline $\begin{array}{l}\text { Organisational } \\
\text { function }\end{array}$ & + & + & + & + \\
\hline $\begin{array}{l}\text { Socio-motivational } \\
\text { function }\end{array}$ & + & - & + & + \\
\hline Technical function & - & - & - & + \\
\hline $\begin{array}{l}\text { Assessment } \\
\text { Metacognitive } \\
\text { function }\end{array}$ & - & - & - & - \\
\hline
\end{tabular}

(-): absence of tutoring / (+): presence of tutoring

In terms of frequency, there is order of importance: The pedagogic function (dominant), organizational function and socio-motivational function. And with less importance: The evaluation function (Absence), the technical function and metacognitive function (still very marginal). 
TABLE V. ANALYSIS OF TUTORSHIP FUNCTIONS FROM THE PLATFORM FOUL

\begin{tabular}{|l|l|}
\hline $\begin{array}{l}\text { Tutor } \\
\text { interventions } \\
\text { (Dominant } \\
\text { function) }\end{array}$ & Analysis \\
\hline $\begin{array}{l}\text { Technical } \\
\text { function }\end{array}$ & $\begin{array}{l}\text { Almost total absence of technical function } \\
\text { because there has been frequent intervention of } \\
\text { the person in charge of FOUL platform to } \\
\text { solve technical problems. }\end{array}$ \\
\hline $\begin{array}{l}\text { Organisational } \\
\text { function }\end{array}$ & $\begin{array}{l}\text { The tutors present at the beginning of training, } \\
\text { objectives, guidelines, etc. } \\
\text { The tutor organizes time, facilitates the } \\
\text { distribution of tasks, and reminds of due dates, } \\
\text { writes summaries..... (4 tutors of responsable } \\
\text { for this experiment). }\end{array}$ \\
\hline $\begin{array}{l}\text { Educational } \\
\text { function }\end{array}$ & $\begin{array}{l}\text { The presence of this function in the practice of } \\
\text { tutors. }\end{array}$ \\
\hline $\begin{array}{l}\text { Pedagogical } \\
\text { function }\end{array}$ & $\begin{array}{l}\text { The presence of this function in the practice of } \\
\text { tutors. }\end{array}$ \\
\hline $\begin{array}{l}\text { Sociomotivational } \\
\text { function }\end{array}$ & $\begin{array}{l}\text { The presence of this function in the practice of } \\
\text { tutors: it encourages, gives meaning to the } \\
\text { learning goals, creates a friendly environment, } \\
\text { creates teamwork spirit, ... }\end{array}$ \\
\hline Assessment & $\begin{array}{l}\text { No assessment in tracing the tutors' } \\
\text { interventions with learners: tutor intervenes in } \\
\text { the hybrid system so summative assessment is } \\
\text { carried in face-to-face. } \\
\text { The trace analysis also revealed that learners } \\
\text { participate in the mutual evaluation of the work } \\
\text { individually or in groups. }\end{array}$ \\
\hline
\end{tabular}

From the table above, certain functions are mobilized enough by all tutors. So there are cardinal functions of tutoring / consensual functions (Denis B, 2003) [9]. These are actually the basic functions: pedagogical, organizational and sociomotivational. The results of this research confirm the presence of these functions to the extent that the later functions remain dominant.

Furthermore, in remote education, it is essential that students have a feedback on their activities to enable them to progress in their learning. Indeed, particular importance was given to the feedback provided on all activities assigned to students. As Rodet stresses (2000, p.46), in remote education, the work of the evaluator is more complex because it "can not limit itself to grading." Thus, the English word "feedback" which indicates that the objective of the evaluater is to give feedback on the work of the learner, Rodet (2000, p.49) [10] defines the term "feedback" as follows: "the feedback comes in response to a work by the learner, (it) offers a guided correction, expresses a value judgment that must be reasoned and argued (and) aims to enable the learner to deepen his knowledge and show him how to do it." But it seemed to us essential to remember is that feedback is "(...) an act of communication which plays a major role in learning" (Rodet, 2000 p.71) [10].

\section{CONCLUSION}

In conclusion, it can be deduced that in the course of this research that the transition from classical education to hybrid education is part of a paradigm shift: like any innovation, its acceptance is likely to be slow since it redefines the task and the roles of the teacher and the student. In addition, the success of a hybrid system is conditioned by the development of the tutoring functions of the teacher / tutor. Indeed, the presence of these functions can influence the motivation, creativity and performance of students. Some language teachers may be surprised by the skills they have to implement and by the interventions they are asked to take, such as (the greeting function, technical, conflict resolution within learner teams, etc.). These tutoring functions emphasize the importance of actual training in the role of the tutor. Tutoring is currently conceived as an obligation and not a choice for any university, mainly those longing to further promote the development of eLearning and the expansion of the hybrid system. Thus, this research has enabled us to formulate results that can be further explored and analyzed in other research projects.

\section{ACKNOWLEDGMENT}

I would like to thank to my advisor Mr. Talbi, $\mathrm{PhD}$, for their invaluable guidance and many useful suggestions during my work on this paper. I would also like to express my gratitude to all those who gave me the possibility to complete this paper.

\section{REFERENCES}

[1] Gilles Willett, Paradigme, théorie, modèle, schéma : qu'est-ce donc ? [Online] mis en ligne le 26 mars 2012, consulté le 13 mars 2016. URL : http://communicationorganisation.revues.org/1873.

[2] Quintin, J.-J. \& Depover, C. \& Degache, C , «Le rôle du scénario pédagogique dans l'analyse d'une formation à distance. Analyse d'un scénario pédagogique à partir d'éléments de caractérisation définis. Le cas de la formation Galanet ». EIAH 2005, Montpellier, France.

[3] RABARDEL P, «Les hommes et les technologies. Approche cognitive des instruments contemporains ». 1995, Paris : Armand Colin.

[4] Kern, R, « La communication médiatisée par ordinateur en langues : recherches et applications récentes aux USA », Le Français dans le monde, Recherches et applications, $\mathrm{N}^{\circ} 40$, Les échanges en ligne dans l'apprentissage et la formation, Paris : Clé international, 2006, pp. 17 29.

[5] Pothier, M., « Multimédias, dispositifs d'apprentissage et acquisition des langues », 2003, Paris : Ophrys.

[6] Glikman, V, «Des cours par correspondance au E-learning », col. Education et formation, 2002, Paris : PUF.

[7] Mangenot F, «Une formation située de futurs enseignants au multimédia », in Tardieu C. \& Pugibet V. Langues et cultures. Les TIC, enseignement et apprentissage, 2005, p. 123-133. Paris, CNDP, Dijon, CRDP de Bourgogne.

[8] Jacques Rodet, Le tuteur à distance et les fonctions d'accompagnement,[Online] mis en ligne Par.jeudi 27 octobre 2011, consulté le 12 mars 2016. URL http://blogdetad.blogspot.com/2011/10/le-tuteur-distance-et-lesfonctions.html .

[9] Denis B., «Quels rôles et quelle formation pour les tuteurs intervenant dans des dispositifs de formation à distance », in Distance et savoirs, vol. I, ${ }^{\circ} 1 / 2003$, p. $1-24$. DOI : $10.3166 /$ ds.1.19-46

[10] Rodet, J, «La rétroaction, support d'apprentissage ? » 2000, Revue du conseil québécois de la formation à distance, 4 . 